\title{
Short Communication: New record of Stenotrophomonas sp. as endosymbiont bacteria in Rhizopus microsporus
}

\author{
DEWI PETI VIRGIANTI ${ }^{1,3, \boldsymbol{v}}$, DESSY NATALIA ${ }^{2}$, I NYOMAN PUGEG ARYANTHA ${ }^{1}$ \\ ${ }^{1}$ Doctoral Program of Biology, School of Life Sciences and Technology, Institut Teknologi Bandung, Jl. Ganesa 10, Bandung 40132, West Java, Indonesia \\ ${ }^{2}$ Biochemistry Research Division, Faculty of Mathematics and Natural Sciences, Institut Teknologi Bandung, Jl. Ganesa 10, Bandung 40132, West Java, \\ Indonesia \\ ${ }^{3}$ Program of Medical Laboratory Technique, Sekolah Tinggi Ilmu Kesehatan Bakti Tunas Husada, Jl. Cilolohan 36, Tasikmalaya 46115, West Java, \\ Indonesia. Tel.: +62-265-334740, `email: dewivirgianti@gmail.com
}

Manuscript received: 9 December 2019. Revision accepted: 27 March 2020.

\begin{abstract}
Virgianti DP, Natalia D, Aryantha INP. 2020. Short Communication: New record of Stenotrophomonas sp. as endosymbiont bacteria in Rhizopus microsporus. Biodiversitas 21: 1678-1685. Rhizopus sp. are closely related to humankind in many aspects of human life. Several species of Rhizopus are important in food, agriculture, and health industries. Rhizopus microsporus has endosymbiont bacteria that has been identified as Burkholderia sp. This study aimed to identify the endosymbiont bacteria in $R$. microsporus isolated from Moringa oleifera Lam leaves. Ring technique, simple method of agar heap technique and antibiotic technique, was conducted to purify the hyphae and to eliminate ectosymbiont and contaminant bacteria outside the hyphae. The presence of endosymbiont bacteria in R. microsporus was determined by using LIVE/DEAD® BacLight Bacterial Viability Kits L13152 and the Fluorescent in Situ Hybridization (FISH) method using EUB338 probes. It was suggested that the culturable endosymbiont bacteria was identified as Stenotrophomonas sp. based on the phylogenetic tree using the 16S rDNA
\end{abstract}

Keywords: Bacterial-fungal interaction, BFI, EHB, endo hyphal bacteria, endosymbiont, FISH, Rhizopus

\section{INTRODUCTION}

Many species of Rhizopus are used in human life, as bioprocess agents in the fermented food industry (Nout and Aidoo 2010) and enzyme industries, and contain various secondary metabolites (Ghosh and Ray 2011; Freitas et al. 2014). However, some species of Rhizopus can cause diseases in plants (Ghosh et al. 2015), post-harvest damage especially in fruits (Kwon et al. 2011) and produce harmful toxins to human (Rohm et al. 2010). Some species of Rhizopus play a role in mucormycosis, especially in immunosuppressed patients (Dolatabadi et al. 2016). Mondo et al. (2017) reported that Burkholderia sp. is mutualistic symbiotic bacteria controls sexual reproduction in Rhizopus sp. However, endosymbiont Burkholderia rhizoxina in $R$. microspores produced rhizoxin ten times in pure culture compared to that in symbiotic forms (Scherlach et al. 2006). The ability of the fungus to produce rhizoxin depends on the presence of endosymbiont bacteria (Partida-Martinez and Hertweck 2005). The first mycotoxin rhizonin is a hepatotoxic cyclopeptide produced in the symbiotic form of low-level fungus $R$. microsporus van Tieghem with Burkholderia bacteria (Partida-Martinez et al. 2007). The transmission process of Burkholderia sp. to $R$. microsporus occur horizontally and vertically (Partida-Martinez et al. 2007; Lackner et al. 2009). Chitinase encoded by the type 2 secretion system (T2SS) gene cluster is used to enter hyphae (Moebius et al. 2014).

The symbiosis between Rhizopus sp. and Burkholderia sp. did not occur in every isolate of Rhizopus. Of the six samples of $R$. microsporus originating from the soil, rice seedlings, and human body tissues, only four species had symbiosis with Burkholderia, namely $R$. microsporus var microsporus and $R$. microsporus van Tieghem var Chinensis (Partida-Martinez and Hertweck 2005). Scherlack et al. (2006) succeeded in finding six different symbionts from a total of $15 \mathrm{R}$. microsporus isolates. The study by Dolatabadi et al. (2016) showed only seven strains (11\%) were positive containing endosymbiont of a total of 64 Rhizopus sp. strains originating from various clinical, environmental, and food samples. Data showed that $85 \%$ of strains containing endosymbiont bacteria were non-clinical samples. The endosymbiotic occurs in Rhizopus sp. originating from various habitats and could not be linked to specific habitats. Data obtained from various studies indicated that the species of $R$. microsporus found symbiosis with $B$. rhizoxina and $B$. endofungarium were derived from soil, rice seedlings, peanuts, Vietnamese Sufu starter, and tempeh (Lacker et al. 2009; Rohm et al. 2010; Dolatabadi et al. 2016). A different genus of endosymbiont bacteria has been isolated from the clinical isolate of $R$. microsporus was identified as Ralstonia pickettii contributing to fungal stress resistance and immune cell evasion as part of fungal pathogenesis in animal models (Itabangi et al. 2019).

The aim of this study was to determine and identify endosymbiont bacteria in Rhizopus sp. isolated from different sources, namely Moringa oleifera leaves. 


\section{MATERIALS AND METHODS}

\section{Procedures \\ Isolation of Rhizopus sp.}

A sheet of $M$. oleifera Lam leaves was ripped and placed on Sabouraud Dextrose Agar (SDA) and incubated for five days. Rhizopus sp. (jamurJP isolate) was purified in a new medium.

\section{Purification of Rhizopus sp.}

Purification of Rhizopus sp. was conducted by eliminating ectosymbiont bacteria using three methods. The three methods were: modified ring method (Raper 1937), simple method of Cother and Priest (2009), and elimination method using ciprofloxacin antibiotics.

Glass ring with $15-20 \mathrm{~mm}$ in diameter, 1-2 $\mathrm{mm}$ wall thickness, and 8-10 $\mathrm{mm}$ height was passed into the fire briefly and cooled again, then pressed in the middle of the SDA as deep as about $5 \mathrm{~mm}$, in which the existing heat residue in the glass ring would be embedded in agar. One needle of fungus was inoculated into the ring, and then its growth was observed for one to two days until the initial hyphal growth. The hyphae were transferred to new sterile SDA media. After five days of incubation at room temperature, the isolate was further purified by cutting a small amount of mycelium and placed on a sterile petri dish. A rectangular SDA was placed on the mycelium, and then small pieces of SDA were placed above the rectangular piece. The culture was incubated until the fungus grew through a rectangular agar and small pieces agar above it. Small fragments of agar were transferred to the new sterile SDA and incubated. Three days culture was inoculated into Trypticase Soy Broth (TSB) containing $0.05 \mathrm{mg} \mathrm{mL}^{-1}$ ciprofloxacin; then incubated overnight at $30^{\circ} \mathrm{C}$. After incubation, broth medium was centrifuged at $4000 \mathrm{rpm}$ for five minutes. The filtrate and supernatant were inoculated separately in SDA containing antibiotics. It was repeated three times.

\section{Identification of Rhizopus sp.}

Identification of Rhizopus sp. was conducted by macroscopic and microscopic observation based on the monograph of Zheng et al. (2007) and followed by molecular identification using ITS3 and ITS4 primers. Genomic DNA extraction was conducted by Quick-DNA ${ }^{\mathrm{TM}}$ Fungal/Bacterial Miniprep Kit (Zymo Research, D6005). Then, PCR amplification was carried out by My Taq Red Mix (Bioline, BIO-25047). PCR product purification was performed by Zymoclean Gel DNA Recovery Kit (Zymo Research, D4002). Sequencing was conducted by Bidirectional sequencing commercially at Genetika Science Indonesia whose data was collected by BLAST using http://www.ncbi.nlm.nih.gov/BLAST/.

Evolutionary analyses were conducted in MEGA7 (Kumar et al. 2016) and concluded using Neighbor-Joining method to obtain the percentage of replicate trees in which the associated taxa clustered in the bootstraps test $(1000$ replicates). The evolutionary distances were calculated using the Maximum Composite Likelihood method.
Observation of endosymbiont bacteria using LIVE/ DEAD® BacLight Bacterial Viability Kits L13152

The stock solution was made by dissolving one pipette of component A (containing SYTO nucleic acid stains) into $2.5 \mathrm{~mL}$ sterile distilled water. One needle of Rhizopus sp. hyphae was placed on the object-glass. The dye solution was dripped sufficiently and covered with a cover glass to avoid evaporation and incubated for 10 minutes at room temperature. It was then observed using fluorescent microscope Fv1200 Olympus Confocal Laser Scanning Microscopy with excitation/wavelength emission of 480/ 500 for live bacteria (green color).

\section{Fluorescent in situ hybridization}

Synthetic oligonucleotide universal probes EUB338 [5'GCTGCCTCCCGTAGGAGT-3'] was used to recognize prokaryotic ribosomal RNAs. The 5' end of the probe was labelled with rhodamine (RHO). One drop of hexamethyldisilazane (HMDS) was applied on clean object-glass, then added with one loop of Rhizopus hyphae, and separated using a needle. Several drops of HMDS were added to the fungus fixation. After being completely dry, about $150 \mu \mathrm{l}$ hybridization buffer containing $50 \mathrm{pmol} / \mathrm{ml}$ probe was applied onto the fungus and incubated in a humidified chamber at room temperature overnight (Fukatsu et al. 1998). The slide was washed using a phosphate buffer solution (PBS) and air-dried to remove non-specific bonds on the probe. The cover slide was applied with specific mounting oil for fluorescence microscopic imaging. The hybridization of a fungus with the probe was observed using fluorescent microscope Fv1200 Olympus Confocal Laser Scanning Microscopy.

\section{Isolation of endosymbiont bacteria}

Isolation of endosymbiont bacteria was conducted according to Partida-Martinez et al. (2007) with a slight modification. One loop of purified five-days-old fungal hyphae was ground using the tip of a sterile stirring rod to break down the hyphae, then planted on TSB media and incubated overnight at $30^{\circ} \mathrm{C}$. The growth of fungi indicated by turbidity of TSB medium. One loop of fungi was taken and transferred to AN medium with a four streaks stroke technique to get a separate colony, and incubated at $37^{\circ} \mathrm{C}$ for 24 hours.

\section{Identification of endosymbiont bacteria}

Identification of endosymbiont bacteria was conducted by molecular identification using $27 \mathrm{~F}$ and $1492 \mathrm{R}$ primers. Genomic DNA extraction with Quick-DNA ${ }^{\mathrm{TM}}$ Fungal/Bacterial Miniprep Kit (Zymo Research, D6005). PCR amplification with MyTaq HS Red Mix (Bioline). PCR using Thermocycler Agilent SureCycler 8800. DNA purified using the Zymoclean Gel DNA Recovery Kit (Zymo Research). Sequencing was done by commercially Bi-directional sequencing at Genetika Science Indonesia. Assembled sequence data were analyzed using BLAST at http://www.ncbi.nlm.nih.gov/BLAST/.

\section{Phylogenetic analysis}

Sequence alignments of sample and reference strains were carried out with Clustal X. Likelihood Model Test was run to determine the best nucleotide substitution model 
using Bayesian analysis. Parameters for Mr Bayes are as follows: 6 substitution types; gamma distribution for among-site rate variation; 200000 generations for Markov Chain Monte Carlo (MCMC) analysis; Sample the MCMC analysis every 1000 generations. Phylogenetic trees were visualized in Treeview.

\section{RESULTS AND DISCUSSION}

\section{Identification of Rhizopus sp.}

Based on the morphology of sporangiophores and sporangium, Rhizopus sp. can be distinguished into three major groups, i.e., stolonifer, arrhizus, and microspores. Stolonifer has the characteristics as follows: sporangiophore length $>1 \mathrm{~mm}$, sporangium diameter 100$275 \mu \mathrm{m}$, and branched rhizoid. Arrhizus characterized by sporangiospores length $>1 \mathrm{~mm}$, sporangiospores diameter $100 \mathrm{~mm}-240 \mu \mathrm{m}$, and branched rhizoid. Microsporus' group characterized by sporangiospores $<0.8 \mathrm{~mm}$, sporangium diameter $<100 \mu \mathrm{m}$, and unbranched rhizoid (Frye and Reinhardt 1993). Previous studies concluded that there are three major groups of Rhizopus based on sporangiophore diameter, namely $6.5 \mu \mathrm{m}$ for $R$. microsporus, $8-10 \mu \mathrm{m}$ for Rhizopus arrhizus, and more than $13 \mu \mathrm{m}$ for Rhizopus stolonifer (Zheng et al. 2007; Gryganskyi et al. 2018). Based on the morphological characters, so Rhizopus sp. (encoded as JamurJP isolate) (Figure 1), was identified as $R$. microsporus.

Molecular identification was conducted to get a reliable identification. The ITS sequence was successfully amplified. The PCR product was shown by DNA fragments at $700 \mathrm{bp}$ (Figure 2). The BLASTN results of the isolate JP from the ITS sequence ( \pm 670 nucleotides) showed the closest relative (100\% similarity) with $R$. microsporus var. chinensis strain CBS 631.82 (MH861534.1) and $R$. azygosporus strain CBS 357.93 (DQ119008.1). A similar result was obtained from the evolutionary analyses by MEGA7, and the robust phylogenetic tree showed that the isolate includes a member of $R$. microsporus clade which contains two varieties member, namely $R$. microsporus var. chinensis and $R$. microsporus var. agyzosporus (Figure 3 ). Rhizopus azygosporus was described as a new species based on a zygospore-like cell formation without fusion between two opposite mating types or sexes (Yuan and Jong 1984). However, it becomes a new strain of $R$. microsporus due to strong similarities in morphological features (Zheng et al. 2007).

Molecular studies based on Genealogies Concordance Phylogenetic Species Recognition (GCPSR) showed distinct variations in topology among the trees so that the $R$. microsporus-related strains should be re-classified as a single species (Liu et al. 2008). The accession number of $R$. microsporus var chinensis strain MH861534.1 has been validated using ITS and LSU and the data has been released to GenBank (Vu et al. 2019). R. microsporus var chinensis has been reported in Chinese koji (China) (Zheng et al. 2007). But, it has never been reported to be found in tempeh inoculum from Indonesia (Hartanti et al. 2015) while $R$. microsporus var. azygosporus CBS 357.93 was originated from the environment and tempeh in Indonesia (Schwarz et al. 2006) which included in one clade with JP isolate in this study.

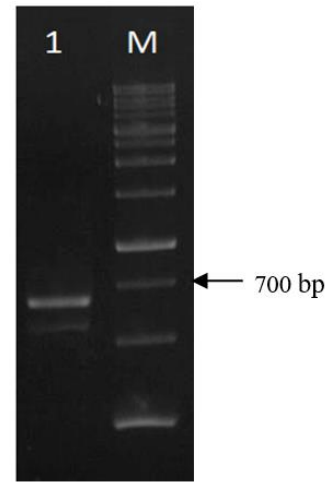

Figure 2. The PCR products by electrophoresis run on $1 \%$ TBE agarose. Rhizopus sp. JamurJP isolate (1) and marker (M).

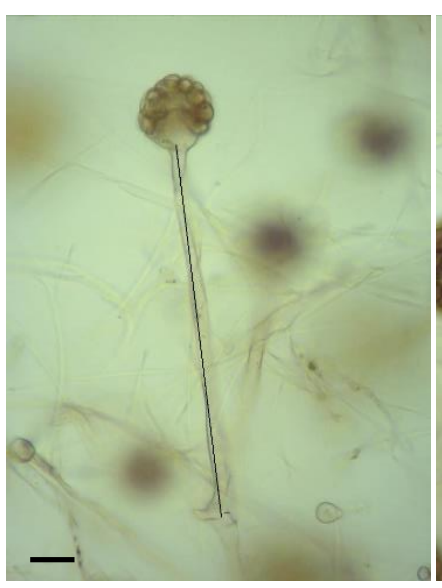

$\mathbf{A}$

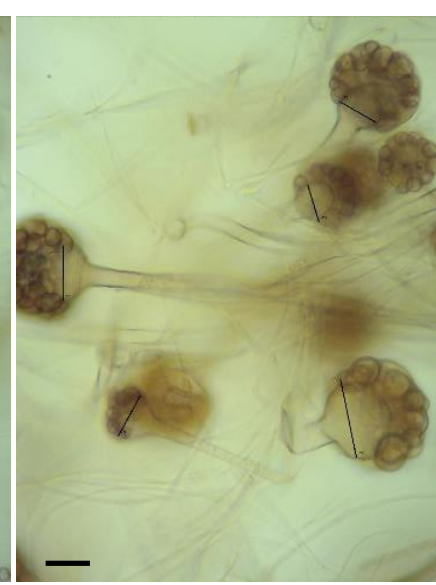

B

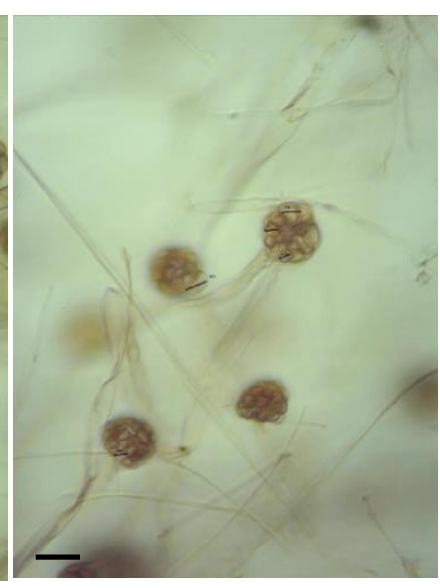

$\mathbf{C}$

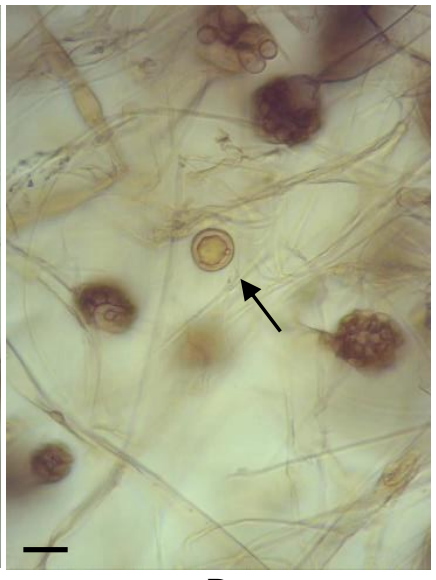

D

Figure 1. The microscopic structure of $R$. microspores. A. length of sporangiophore $<0,8 \mathrm{~mm}$; B. spore diameter $\pm 6,5 \mu \mathrm{m}$; C. sporangium diameter < $100 \mu \mathrm{m}$; and D. zygospore. Scale bar: $20 \mu \mathrm{m}$. 


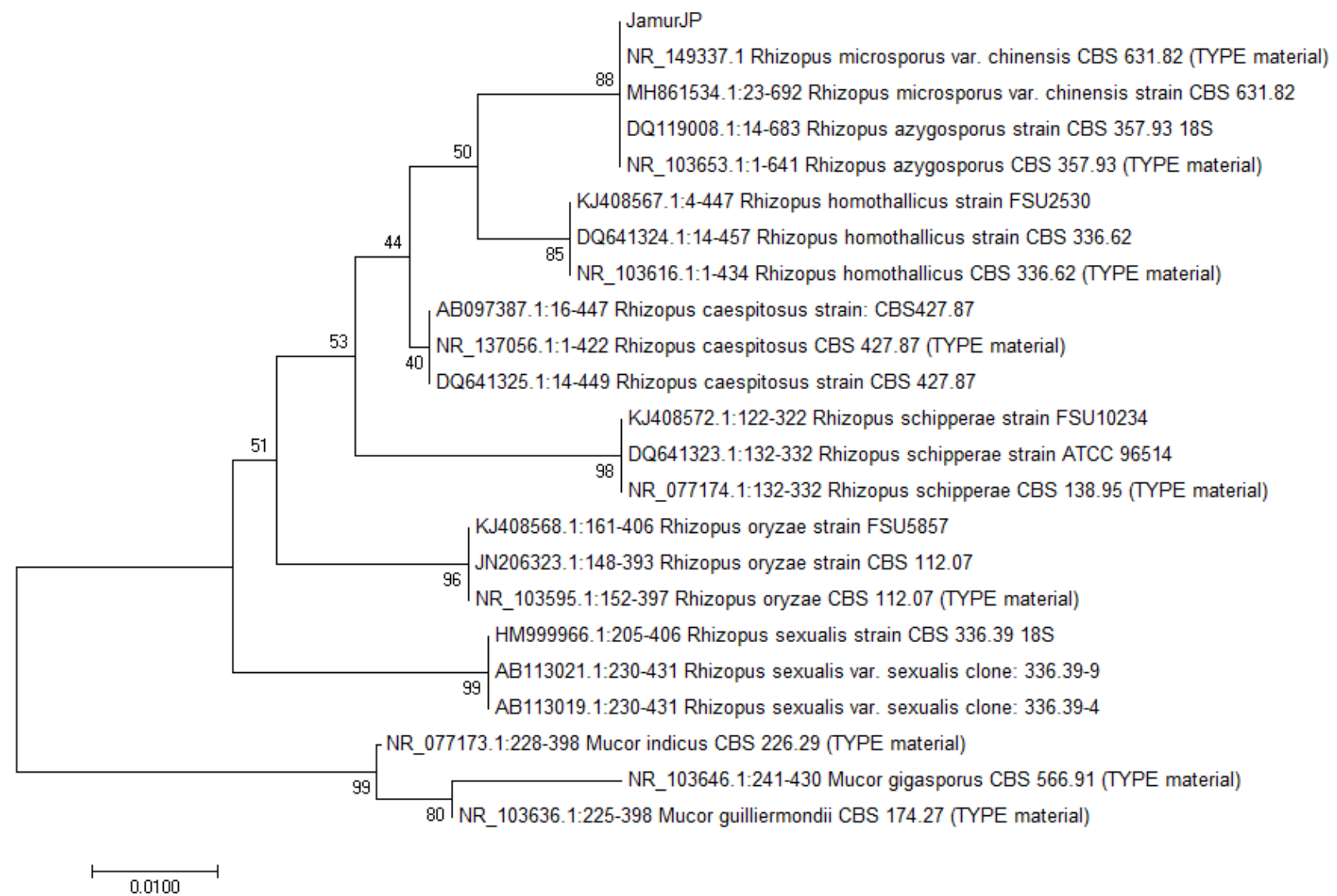

Figure 3. Neighbor-joining phylogenetic dendrogram based on ITS sequences showed the phylogenetic relationship between isolate JamurJP and closely related strain to $R$. microsporus. Bootstrap values based on 1000 replicates are shown at branch nodes. The tree placed the JamurJP isolate into $R$. microsporus clade which contains two varieties namely $R$. microsporus var chinensis and $R$. microsporus var. azygozporus.

Rhizopus sp. obtained in this study was isolated from the surface of Moringa leaves. Rhizopus sp. was discovered in many leaves, including wrapping leaves such as teak and banana leaves (Dewi and Azis 2011), and waru leaves (Dewi and Azis 2011; Barus et al. 2019).

\section{Observation of endosymbiont bacteria using LIVE/ DEAD® BacLight Bacterial Viability Kits L13152.}

Physical associations between fungi and bacteria are varied, some of which form non-permanent communities consisting of various microbes, but some others form particular associations (Frey Klet et al. 2011). Physical symbiosis could be classified as ectosymbiont if the bacteria were outside the fungal plasma membrane, and as an endosymbiont, if the bacteria were inside the fungal cell.

The presence of endosymbiotic bacteria in Rhizopus sp. encoded JamurJP could be observed with a bacterial viability staining kits illuminating the green color, which indicated that cells still-alive and have an intact membrane (Figure 4). Endosymbiont bacteria were still detected in the hyphae despite three stages of purification. It may be due to bacterial resistance or the failure of antibiotics to penetrate the hyphae. It can also show that there was an obligate relationship between bacteria and fungi
(Fitzpatrick 2013). Association between many foliar fungi and endosymbiont bacteria called endo hyphal bacterial (EHB). EHB was suggested as facultative EHB in the hyphae when it could be eliminated by using antibiotics (Arendt et al. 2016). The endosymbiont bacteria obtained in this study were able to grow in the standard growth media, but unable to grow when transferred to growth media containing antibiotics. It might suggest the obligate relationship between these fungi and bacteria (Hoffman and Arnold 2010).

Several studies on the physical association between bacteria and endosymbiont fungi had been conducted on many fungal species. Cruz and Ishii (2011) show that probable endobacteria (PE) in Gigaspora margarita were identified as Bacillus sp, Bacillus thuringiensis, and Paenicbacillus rhizospherae. The study by Hoffman and Arnold (2010) showed that Proteobacteria and Bacillaceae were endosymbionts in endophytic fungi Pezizomycetes, Dothideomycetes, Eurotiomycetes, and Sordariomycetes. Sato et al. (2010) reported that Betaproteo bacteria was endosymbiont in the mycelium of Mortiella elongate. Desiro et al. (2015) reported that Mollicutes-related endobacteria (Mre) embedded in the Endogone fungal cytoplasm. 


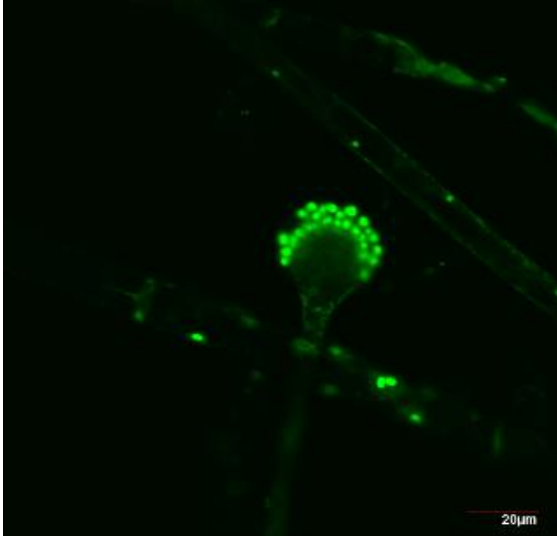

A

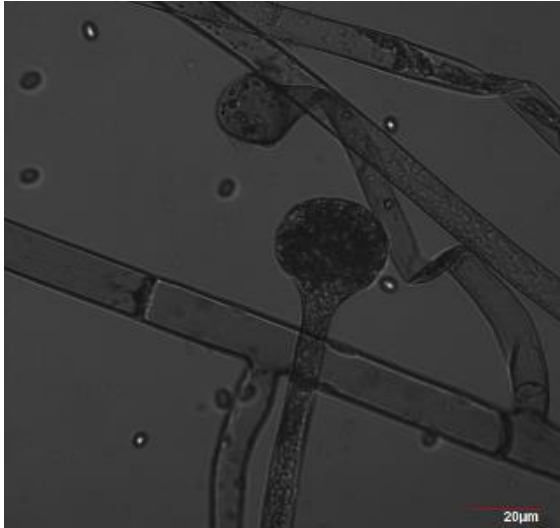

B

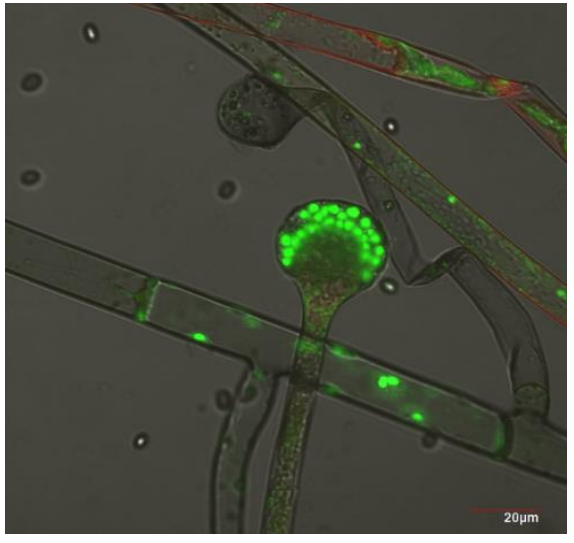

C

Figure 4. The presence of endosymbiotic bacteria living in Rhizopus was detected by the appearance of bright green luminescence from the SYTO 9 dye coloring the intact membrane cell (A). DIC (Differential interference contrast) (B). Mixed image (C)

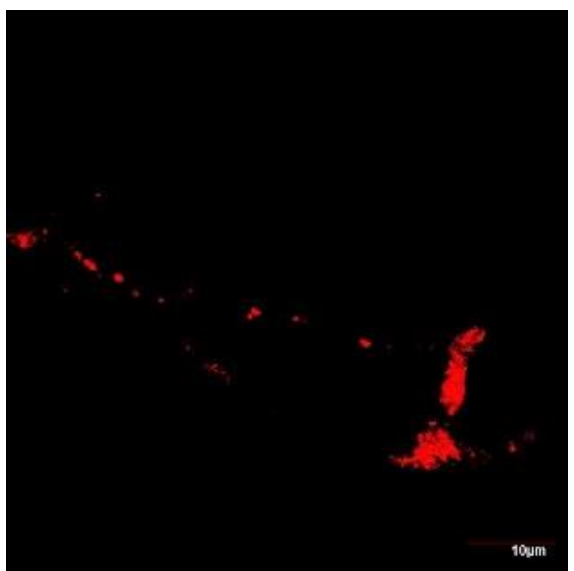

A

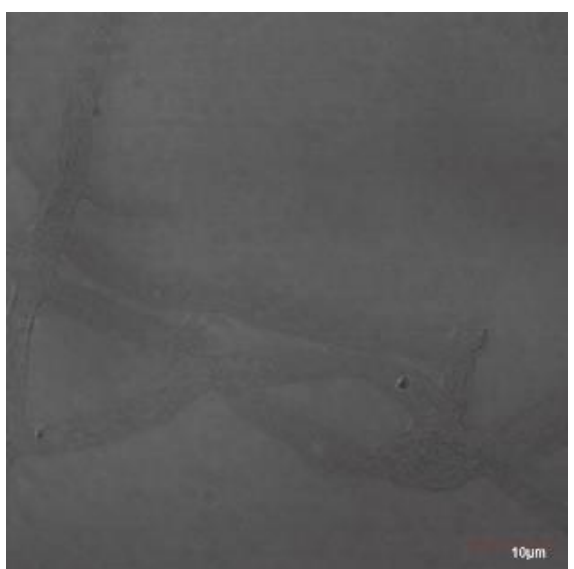

B

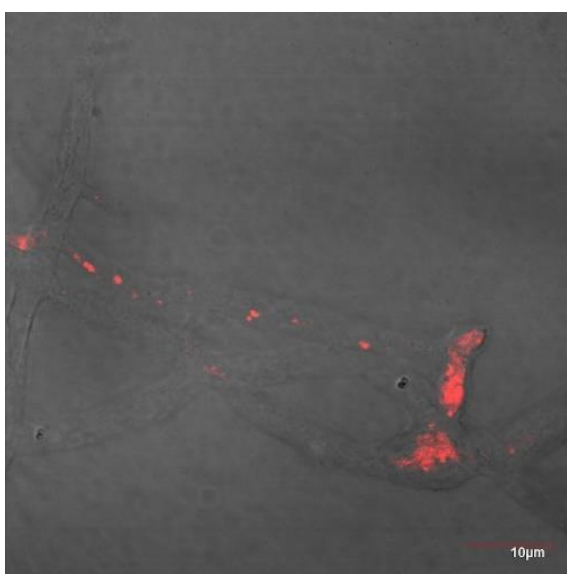

C

Figure 5. Endosymbiont bacteria were recognized by the appearance of the bright red color of universal bacterial probe EUB338 RHOlabeled (A). DIC (B). Mixed image (C). Synthetic oligonucleotide universal probes EUB338 [5' -GCTGCCTCCCGTAGGAGT-3'] was used to recognize prokaryotic ribosomal RNAs. The 5' end of the probe was labeled with rhodamine (RHO)

\section{Fluorescent in situ hybridization}

The EUB338 probe labeled with RHO succeeded to recognize bacterial ribosomal RNAs by displaying red color under fluorescence microscopic (Figure 5). This result indicated that putative bacterial endosymbiont was present within the hyphae of Rhizopus sp. encoded JamurJP. The probe used was a universal probe for bacteria, so it was not able to indicate to specific species. Further bacterial isolation and identification must be done to prove its existence.

\section{Isolation and identification of endosymbiont bacteria}

Isolation of endosymbiont bacteria was conducted by grinding hyphae in several tubes. The growth of bacterial isolate was characterized by changes in turbidity in the tube. One isolate that was successfully cultured, purified and characterized by molecular identification was endosymbiont encoded as JMJP.

The 16S rRNA sequence of the JMJP endosymbiont was successfully amplified. PCR products showed DNA fragments at $1500 \mathrm{bp}$ (Figure 6). The BLASTN results of the $16 \mathrm{~S}$ rRNA sequence $( \pm 1404$ nucleotides) showed the similarity of endosymbiont JMJP with $S$. pavanii strain LMG 25348 (99.86\%), followed by S. mathophilia strain IAM 12423 (99.57\%), S. tumulicola (98.44\%), $S$. chelatipaga $(98.22 \%)$, and S. bentonitica $(98.12 \%)$. Based on pairwise sequence similarities, it showed that endosymbiont JMJP has similarity $<98 \%$ with other bacteria species of the genus Stenotrophomonas. A similar result was generated based on evolutionary analyses conducted by Mr.Bayyes, the robust phylogenetic tree (Figure 7) suggests that the closest relatives of endosymbiont JMJP is S. pavanii strain LMG 25348.

Based on NCBI information, $S$. pavanii strain LMG 25348 was obtained from direct submission from the culture collection, so there is no identifiable information. Endosymbiont JMJP bacteria has sequence similarity of $99.43 \%$ to $S$. pavanii strain ICB 89. S. pavanii is Gramnegative, rod-shape, non-spore formation, and endophytic nitrogen-fixing bacteria. It was isolated from Brazilian 
sugar cane stems (Ramos et al. 2011). The genus Stenotrophomonas was phenotypically and genetically heterogeneous (Ryan et al. 2009; Vasileuskaya-Schulz 2011), which currently consisted of 13 recognized species validated in prokaryotic nomenclature https://www.catalogueoflife.org/col/search/all/key/Stenotro phomonas.

$S$. pavanii shows typical morphological and biochemical characteristics so that it can be clearly distinguished from other members of the genera Stenotrophomonas and Pseudomonas (Ramos et al. 2011). Moreover, strain S. pavanii ICB 89 showed mean DNADNA relatedness below $70 \%$ with S. maltophila, [P.] geniculata, [P.] beteli, S. rhizophila and S. nitritireducens which were clearly below cut-off value for species delineation (Ramos et al. 2011).

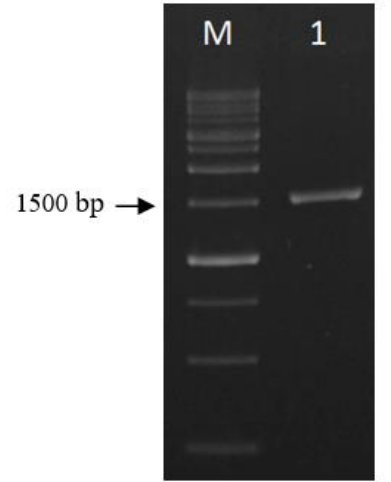

Figure 6. The PCR products by electrophoresis run on 1\% TBE agarose. Endosymbiont bacteria (1) and marker (M).

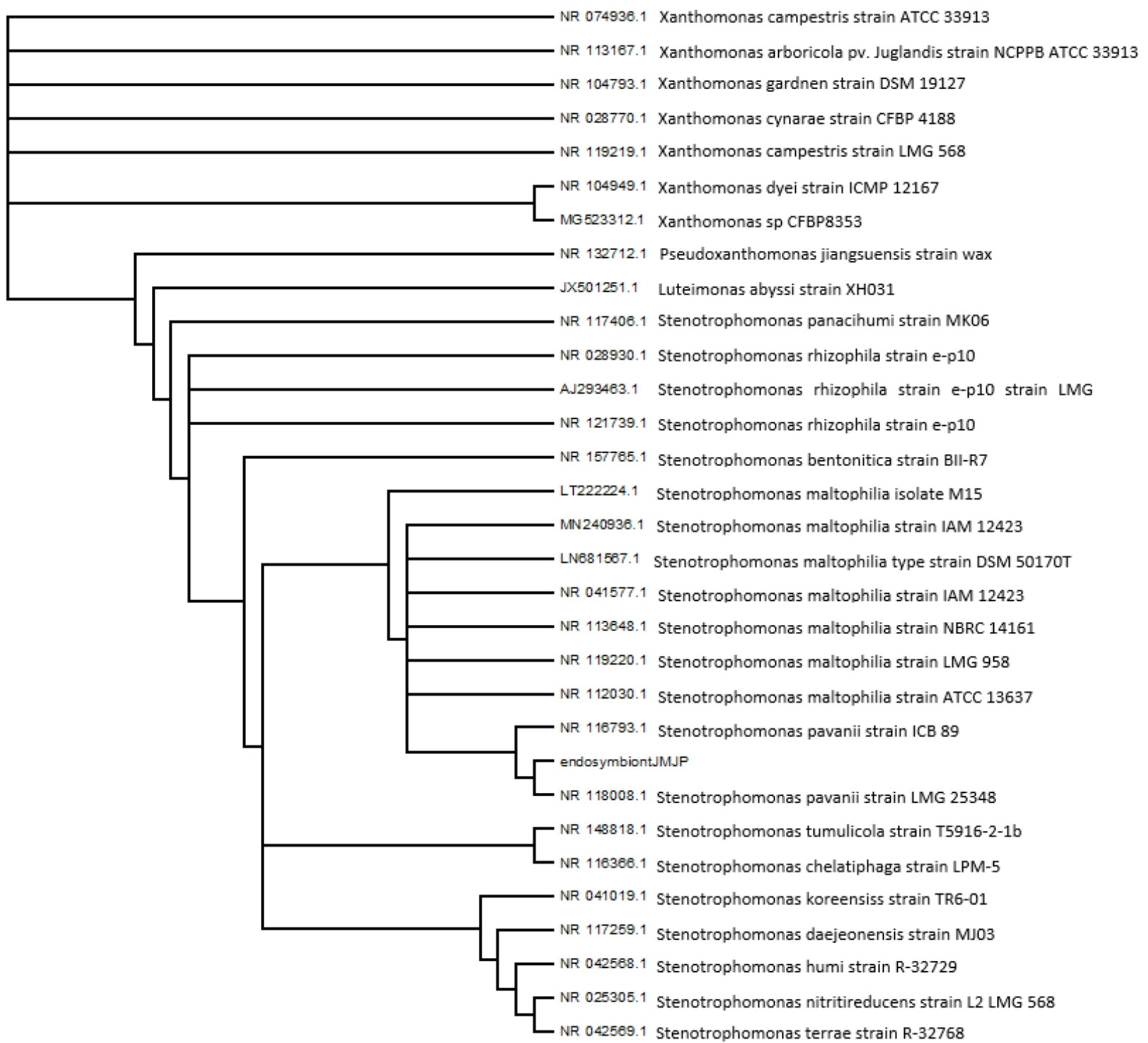

Figure 7. Phylogenetic analysis tree obtained from the alignment of the 16S rDNA of the endosymbionts JMJP from Rhizopus sp. with the closest bacterial sequences retrieved by a BLAST search. Evolutionary analyses were conducted by Likelihood Model in Bayesian analysis. The evolutionary tree showed that endosymbiont JMJP is one clade with $S$. pavanii strain 
Although the origin of endosymbiont bacteria in fungi is not known, their existence is very closely related to their habitat. Even though generally the phylogenetic relationship between endosymbiont bacteria as fungal endophytes were not congruent with the host plant nor with endophytes they inhabit, one genotype represented as the same order as Bacillales both among putative EHB in fungal endophytes and bacterial endophytes isolated from J. deppeana foliage (Hoffman and Arnold 2010). The close relationship between symbiont and its host result enables transmission. Recent studies showed that plant-fungus interaction could be altered by plant-associated fungi containing endosymbiont bacteria (Salvioli et al. 2016; Hoffman et al. 2016; Partida-Martinez and Hertweck 2005). Fungi could produce their secondary metabolites, but in some cases, the influence of the endosymbiont bacteria triggered the fungus to produce certain substances affect positively or negatively on the host plant. Endophytic fungus Pestalotiopsis sp. 9143 contained Luteibacter sp. as EHB, which can increase the ability for hydrolytic enzymes and auxin production (Hoffman et al. 2013; Arendt et al. 2015). B. rhizoxina, as an endosymbiont bacterium of $R$. microsporus, produced a toxin that enables its host to cause disease in rice plants (Partida-Martina et al. 2007). Chitinophaga sp. as EHB can alter carbon source used by Fusarium keratoplasticum, which potentially formed fungal ecology and fungal-plant interaction (Shaffer et al. 2017).

In conclusion, the new genus of endosymbiont bacteria in $R$. microsporus has been identified in this study. Study on the diversity of endosymbiont in Rhizopus sp.from different habitats, especially those associated with plants, should be done. Further study may focus on the role of these bacterial-fungal interactions and its complex relationship with fungal-plant interaction.

\section{ACKNOWLEDGEMENTS}

This research was funded by Budi-DN Scholarship.

\section{REFERENCES}

Arendt KA, Hockett KL, Araldi-Brondolo SJ, Baltrus DA, Arnold AE. 2016. Isolation of endohyphal bacteria from foliar Ascomycota and in vitro establishment of their symbiotic associations. Appl. Environ. Microbiol 82: 2943-2949. DOI: 10.1128/AEM.00452-16

Arendt KA. 2015. Symbiosis Establishment and Ecological Effects of Endohyphal Bacteria on Foliar Fungi. [Thesis]. University of Arizona, Tucson. AZ.

Barus T, Halim R, Hartanti AT, Saputra PK. 2019. Genetic diversity of Rhizopus microsporus from traditional inoculum of tempeh in Indonesia based on ITS sequences and RAPD marker. Biodiversitas. 20 (3): 847-852.

Cother NJ, Priest MJ. 2009. A simple and effective method for the elimination of bacteria from fungal cultures. Australasian Plant Pathol 38: 132-134.

Cruz AF, Ishii T. 2011. Arbuscular mycorrhizal fungal spores host bacteria that affect nutrient biodynamics and biocontrol of soilborne plant pathogens. Biol Open 1: 52-57.
Desiro A, Faccio A, Kaech A, Bidartondo MI, Bonfante P. 2015. Endogone, one of the oldest plant-associated fungi, host unique Mollicutes-related endobacteria. New Phytol 205: 1464-1472.

Dewi RS, Aziz S. 2011. Isolasi Rhizopus oligosporus pada beberapa inokulum tempe di Kabupaten Banyumas. Molekul. 6 (2): 93-104. [Indonesian]

Dolatabadi S, Scherlach, Figge M, Hertweck C, Dijksterhuis J, Menken SBJ, Hogg SD. 2016. Food preparation with mucoralean fungi: a potential biosafety issue? Fungal Biol 120: 393-401.

Fitzpatrick EE. 2013. First Bacterial Endosymbionts Found in the Phylum Ascomycota. Department of Biology. Portland State University, Portland, OR.

Freitas AC, Escaramboni B, Carvalho AFA, de Lima VMG, de OliviaNeta P. 2014. Production and application of amylases of Rhizopus oryzae and Rhizopus microsporus var. oligosporus from industrial waste in acquisition of glucose. Chem Papers 68 (4): 442-450.

Frey-Klett P, Burlinson P, Deveau A, Burret M, Tarkka M, Sarniguet A. 2011. Bacterial-fungal interaction: hyphens between agricultural, clinical, environmental, and food microbiologists. Microbiol Mol Biol Rev 75 (4): 583-609. DOI: 10.1128/MMBR.00020-11

Frye CB, Reinhardt.1993. Characterization of groups of the zygomycete genus Rhizopus. Mycopathologia 124: 139-147.

Ghosh B, Ray RR. 2011. Current commercial perspective of Rhizopus oryzae: A Review. J Appl Sci 11 (14): 2470-2486.

Ghosh R, Barman S, Mukhopadhyay A, Mandal NC. 2015. Biological control of fruit rot of jackfruit by rhizobacteria and food-grade lactic acid bacteria. Biol Control 83: 29-36.

Gryganskyi AP, Golan J, Dolatabadi S, Mondo S, Robb S, Idnurm A, Muszewska A, Steczkiewicz K, Masonjones S, Liao H-L, Gajdeczka MT, Anike F, Vuek A, Anishchenko IM, Voigt K, de Hoog GS, Smith ME, Heitman J, Vilgalys R, Stajich JE. 2018. Phylogenetic and Phylogenomic Definition of Rhizopus Species. G3 Genes Genome Genetics. 8 (6): 2007-2018. DOI: 10.1534/g3.118.200235.

Hartanti AT. Rahayu G, Hidayat I. 2015. Rhizopus species from fresh tempeh collected from several regions in Indonesia. Hayati J Biosci. 22: 136-142. DOI: 10.1016/j.hjb.2015.10.004

Hoffman MT, Arnold AE. 2010. Diverse bacteria inhabit living hyphae of phylogenetically diverse fungal endophytes. Appl Environ Microbiol 76: 4063-4075. DOI: 10.1128/AEM.02928-09

Hoffman MT, Gunatilaka MK, Wijeratne K, Gunatilaka L, Arnold AE. 2013. Endohyphal bacterium enhances production of indole-3-acetic acid by a foliar fungal endophyte. PLoS ONE. 8:e73132. DOI: 10.1371/journal.pone.0073132.

Itabangi H, Sephton-Clark PCS, Zhou X, Insua I, Probert M, Correia J, Moynihan P, Gebremariam T, Gu Y, Lin L, Ibrahim AS, Brown GD, King JS, Trillo FF, Ballou ER, Voelz K. 2019. A bacterial endosymbiont enables fungal immune evasion during fatal Mucormycete infection. bioRxiv: 584607. DOI: DOI: 10.1101/584607.

Kumar S, Stecher G, Tamura K. 2016. MEGA7: Molecular Evolutionary Genetics Analysis version 7.0 for bigger datasets. Mol Biol Evol 33: 1870-1874.

Kwon JH, Kim J, Kim W. 2011. First report of Rhizopus oryzae as a postharvest pathogen of Apple in Korea. Mycobiology 39 (2): 140142.

Lackner G, Nadine M, Scherlach K, Partida-Martinez LP, Winkler R, Schmitt I, Hertweek C. 2009. Global distribution and evolution of a toxinogenic Burkholderia-Rhizopus symbiosis. Appl Environ Microbiol 75 (9): 2982-2986.

Liu X-y, Huang H, Zheng R-y. Molecular phylogenetic relationship within Rhizopus based on combined analyses of ITS rDNA and pyrG gene sequences. Sydowia. Intl J Micol 59 (2): 235-253.

Moebius N, Uzum Z, Dijksterhuis J, Lackner G, Hertweck C. 2014. Active Invasion of Bacteria Into Living Fungal Cells. eLife. 3: e03007. DOI: 10.7554/eLife.03007

Mondo SJ, Lastovetsky OA, Gasper ML, Schwardt NH, Barber CC, Riley R, Sun H, Griguriev IV, Pawlowska TE. 2017. Bacterial endosymbiont influence host sexuality and reveal reproductive genes of early divergent fungi. Nature 8: 1843.

Nout MJR, Aidoo KE. 2010. Asian fungal fermented food. In M Hofrichter (ed.). Industrial Applications. Springer. Berlin. Germany. The Mycota 10 (2): 30-58

Partida-Martinez LP, Hertweck. 2005. Pathogenic fungus harbours endosymbiotic bacteria for toxin production. Nature. 437: 884-888. 
Partida-Martinez LP, Monajembashi S, Greulich O, Hertweck C. 2007. Endosymbiont-Dependent Host Reproduction Maintains BacterialFungal Mutualism. Curr Biol. 17: 773-777.

Ramos PL, Van Trappen S, Thompson FL, Rocha RC, Barbosa HR, De Vos P, Moreira-Filho CA. 2011. Screening for endophytic nitrogenfixing bacteria in Brazilian sugar cane varieties used in organic farming and description of Stenotrophomonas pavanii sp. Nov. Int J Syst Evol Microbiol. 61 (Pt 4): 926-31. DOI: 10.1099/ijs.0.019372-0. PMID 20495025

Raper JR. 1937. A method of freeing fungi from bacterial contamination. Am Assoc Adv Sci Pub. 85: 342.

Rohm B, Scherlach K, Mobius N, Partida-Martinez LP, Hertweck C. 2010. Toxin production by bacterial endosymbionts of Rhizopus microporus strain used for tempe/sufu processing. Intl J Food Microbiol 136: 368-371.

Ryan RP, Monchy S, Cardinale M. 2009. The versatility and adaptation of bacteria from the genus Stenotrophomonas. Nat Rev Microbiol 7 514-525.

Salvioli A, Ghignone S, Novero M, Navazio L, Venice F, Bagnaresi P, Bonfante P. 2016. Symbiosis with an endobacterium increases the fitness of a mycorrhizal fungus, raising its bioenergetic potential. ISME J. 10: 130-144. DOI: 10.1038/ismej.2015.91

Sato Y, Narisawa K, Tsuruta K, Umezu M, Nishizawa T, Tanaka K, Yamaguchi K, Komatsuzaki M, Ohta H. 2010. Detection of Betaproteobacteria inside the mycelium of the fungus Mortierella elongate. Microbes Environ 25: 321-324.
Scherlach, Partida-Martinez LP, Dahse HM, Hertweck C. 2006. Antimitotic Rhizoxin Derivatives from culture Symbionts of the Rice Pathogenic Fungus Rhizopus microsporus. J Am Chem Soc 128: 11529-11536. DOI: 10.7554/elife.03007

Schwarz P, Bretagne S, Gantier J-C, Garcia-Hermoso D, Lortholary O, Dromer F, Dannaoui E. 2006. Molecular identification of zygomycetes from culture and experimentally infected tissue. J Clin Microbiol 44 (2): 340-349. DOI: 10.1128/JCM.44.2.340-349.2006.

Shaffer JP, U'ren JM, Gallery RE, Baltrus DA, Arnold AE. 2017. An endohyphal bacterium (Chitinophaga, Bacteroidetes) alters carbon source use by Fusarium keratoplasticum ( $F$. solani species complex, Netriaceae). Front Microbiol 8: 350. DOI: 10.3389/fmicb.2017.00350

Vasileuskaya-Schulz Z, Kaiser S, Maier T, Kostrzewa M, Jonas D. 2011. Delineation of Stenotrophomonas spp. by multi-locus sequence analysis and MALDI-TOF mass spectrometry. Syst Appl Microbiol 34 (1): $35-39$

Vu D, Groenewald M, de Vries M, Gehrmann T, Stielow B, Eberhardt U, Al-Hatmi, Groenewald JZ, Cardinali G, Houbraken J, Boekhout T, Crous PW, Robert V, Verkley GJM. 2019. Large-scale generation and analysis of filamentous fungal DNA barcodes boosts coverage for kingdom fungi and reveals thresholds for fungal species and higher taxon delimination. Stud Mycol 9 (2): 135-154. DOI: 10.101666/j.simyco.2018.05.001

Yuan G.-F, Jong S-C. 1984. The new species Rhizopus azygosporus for manufacture of tempeh. Mycotaxon 20: 397-400.

Zheng R, Chen G, Huang H, Liu X. 2007. A monograph of Rhizopus. Sydowia 59 (2): 273-372. 